University of Lodz

\title{
BELFAST REALISM: NORTHERN CITY-SCAPES IN CHRISTINA REID'S DRAMA
}

\begin{abstract}
Christina Reid was a Northern Irish playwright whose plays maintained a distinctly socially-oriented perspective. In her works from 1980s and 1990s, she penetrated spaces of Belfast city inhabited by marginalized, Protestant working-class communities. Her writing stands in conspicuous contrast to stereotypical plays written in the South of the island. If the South playwriting could be associated with imaginative, poetic, unrealistic representation of rural life on the one hand, and traditional, Gaelic heritage on the other, the Belfast scenery is that of working-class, post-industrial depression. Here, political violence equals social injustice, contributing to the realistic presentation of characters on the verge of survival in socially, economically, and politically troubled environment.

Reid's writing can also be deconstructed as a specific example of vision stimulated by marginalised location in the north - the north understood not as an affluent, middle-class, Eurocentric geography of continental capitals but as a province of Western world torn with political and economic problems. This article argues that knowledge is located in particular material circumstances and that it is to some extent produced by the geographic conditions of its existence. Many literary works conceived in Northern Ireland, Reid's drama included, develop their own language of analysis and description, their own discourse of survival in which their peculiar conditions are uniquely phrased and in which an intriguing perspective from the margins of Western culture is coined. The aim of the article is to analyse how Christina Reid and her plays produce a characteristic language, dialogue, diction of the north and how these forms of communication, both linguistic and theatrical, reflect back on the dominating knowledge of Irish as well as central European cultures.
\end{abstract}

Keywords: Christina Reid, Northern Irish drama, the Troubles, postcolonialism, Belfast

1.

Reading of Northern Irish literature, which to a decisive majority of readers is simply a marginal body of work, may provoke diagnostic reflections on European culture and politics, the condition of democracy and its institutions. George Orwell's debut novel, Burmese Days, was to a large extent a pessimistic assessment of the dif- 
ficult predicament of the British empire and its colonial administration viewed from a distant location of Burma and through the eyes of a shy merchant. If the foreign imperial rule slowly sinking into a state of decomposition could be any indication of the condition of the metropolis and by implication of the entire empire, then perhaps Northern Irish experience - produced largely by British colonial presence on the island - can say something about the condition of Europe, its democratic institutions and societies. This article focuses in particular on dramatic works of Christina Reid, a protestant working-class writer from Belfast, whose plays present life in 1980s, the time of intense sectarian violence in the region. Reid's writing shows the rule of populist politics in a semi-democratic state which withdraws from its basic social and moral responsibilities to make space for violence, populism and the domination of criminally empowered politicians. Although Reid's work concentrates on a detailed presentation of Belfast in 1980s, a city torn apart by Northern Irish conflict, her images strikingly resemble today's Europe, the continent increasingly divided by walls and borders. They may be mental or symbolic just for now; yet, with a stroke of bad luck, the continent will end up looking as divided and conflicted as the map of the city taken over by Loyalist and Republican paramilitaries who carefully guard their own territories. After a period in the 1990s when Europe had no borders, the times of the troubles return, and demarcation lines again offer a delusive promise of peace and stability. Belfast peace-walls suggest the opposite. Reid's characters, whose lives she follows in a realistic, detailed presentation of existence devastated by political and military violence, develop strategies of evasion, showing what it means to live in an environment where individual and political identities rest on solid ground of dogma and fanaticism. If there is any lesson to be taken from studying earlier conflicts, it is among others to learn about social and personal costs paid by those who are passive victims of populist ideologues. Christina Reid's characters face this danger exactly.

It is possible to see Northern Irish troubles, its political and social tensions, not exclusively as a local conflict, but as an important indication of weakness and shortcomings of the entire political system which defines European democracy in the postwar period. In other words, Northern Irish Troubles would be only a more extreme version of exactly the same crisis which begins to crumble European political institutions towards the end of the twentieth century and at the beginning of the new millennium. In other words, what Northern Irish literature says about its regional politics, society and life possesses a diagnostic capacity for the condition of European values; similarly, the way Northern Irish politics can be read from further afield produces some universal patterns of understanding not only for the region itself but for the rest of the continent.

Therefore, this article analyses a local field of Northern Irish drama in which many general forces not only acquire significant intensity magnified in individual lives, private stories, or domestic experience, but also engage with specific politics of the place as well as with multiple literary traditions of their representation. Northern Irish drama, or rather selected works of one playwright, offer a productive case 
study to reflect on the conditions of generating a particular knowledge of the place, reflecting a localized experience of life in Belfast whose history and identity remain inextricably linked with major political tensions of the second half of the twentieth century. It is assumed that even a single literary text, or a dramatic script, can be read as an adequate rendering of specific, historical moments, in all their shifting impermanence, and as a document of the time in which general patterns provide structures of reading imperceptible to those who lived in this specific period and place but applicable beyond their locality. The main focus of the analysis is to describe how Reid's largely female protagonists develop individual, private strategies of survival, of subversion towards the system, of maintaining interpersonal relation within an alternative community which escapes the dogmatic ideologies of the official politics. It is a story in which private practices of life penetrate cracks of the system in a state of disintegration.

Christina Reid (1942-2015), born into a Protestant working-class Belfast family, produced plays openly confronting issues of poverty, social injustice, violence, strong political divisions, gender inequality, and criminality of urban environment in a world which was completely dependent on sectarian power-struggle between local communities as well as on post-colonial politics of Westminster. The plots of her drama penetrate the spaces which lie in the heart of conflict in all dimensions which Northern Ireland and Belfast have experienced since the beginning of the previous century when the island was divided between two countries. Her protagonists are recruited from Protestant working-class families whose privileged social position within the post-imperial society of the UK's province of Ulster does not translate into real material wealth or prosperity, better job opportunities, adequate political representation or social benefits which would be capable of alleviating the hardships of living under strain of a struggling economy on the margins of the fallen empire. Christina Reid tackles these issues very practically through realistic or even naturalistic lens of an acute social observer, based on foregrounding practical dilemmas and tragedies of life within the community divided by decades of atrocities and violence performed within one single neighbourhood, or even in a single street. Reid knew these conditions of life intimately not only through her family background but also through personal observation. She left school early to raise her children, and only later did she take up reading English, sociology and Russian at Queen's University Belfast. ${ }^{1}$ She left university after one year to devote herself to writing and staging her plays full time. ${ }^{2}$ She was actively involved in a variety of social rehabilitation programmes for difficult youth, and during her writer's residency at the Lyric Theatre

M.M. Delgado, "Introduction”, [in:] Ch. Reid, Plays 1, London: Methuen, 1997, p. vii.

D. Roll-Hansen, "Dramatic strategy in Christina Reid's Tea in a China Cup", Modern Drama 1987, vol. 30(3), p. 390. 
Belfast (1983-1984), she led a number of creative-writing workshops for children and teenagers. She was also appointed Governor of the Linen Hall library in Belfast. ${ }^{3}$

Stories dramatized in her plays come largely from experience and from what she collected listening to conversations of those she tutored. Tea in a China Cup (1983) tells about a Protestant family who cope with destructive forces of history and local politics. Its efforts to fight them are combined with attempts to preserve the memories accumulated through the family's long past. We move across a wide span of history from the first world war, through the year 1939 to the 1970s, watching young men marching away to fight in these global and national conflicts. What is left are Protestant women, keeping photos of their late husbands and sons, as well as cultivating stories of their life and death. Interspersed with memories recollected by women whose cultural memory stands for the entire community, not just an individual remembrance, the play offers pictures of a difficult process of coming to terms with harsh conditions of life, which have been imposed on the female protagonists rather than having been chosen by them. Did You Hear the One about the Irishman...? (1985) presents a tragic story of love between teenage youths from Protestant and Catholic backgrounds. Alison's and Brian's families are unified by one thing and one thing only, they hate the idea of marriage across the religious and political divide. The young couple's spontaneous devotion to each other, which flourishes against the odds of a growing sectarian disagreement and irritation, ends in their deaths at the hands of militant organisations, which can easily sacrifice innocent life for the sake of keeping the flame of war burning. In Joyriders (1986), Reid dramatizes the story of a youth organization run in the notorious Divis Flats district of Belfast by a young, enthusiastic social worker. It is a place of encounter, work and play for kids from troubled areas of the city in which the violence of life effectively destroys any possibility of a successful rehabilitation. Finally, The Belle of the Belfast City (1989) tells the story of a little convenience shop in Belfast, which is owned by a multi-generational family of largely Protestant leaning. The shop's existence as well as the family's peace are constantly disrupted by hostile activities of local Protestant politicians and activists, by street marches and riots and by lack of tolerance within the divided family. Through these plots Reid manages to tell tales of socially-engaged realism and authenticity in which specific stories of Belfast women reflect on more universal philosophical agendas of justice, equality and democracy. A consistently maintained female perspective imposes a different set of themes than the one typically present in the male dominated arena of politics. Using vulnerability as a defining feature of the non-militant and sensitive protagonists whose lives are permanently dependent on instability and public unrest, Reid dissociated

A very comprehensive introduction into Christina Reid's literary career as well as biographical background can be found in a recently published monograph by R. Tracie, Christina Reid's Theatre of Memory and Identity: Within and Beyond the Troubles, Cham: Palgrave Macmillan, 2018. 
Northern Irish conflict from its most typical reference points defined by terrorism, punishment shootings and riots. ${ }^{4}$

Naturally, Christina Reid's work belongs to a broader phenomenon known in critical reception as the "flowering of «Troubles Drama»", 5 and continuing a specific, local tradition of Ulster revival in literature from the beginning of the twentieth century. Although the "North" has produced a number of authors whose writing and diction might not form a unified school of writing, it is especially vital to stress that works of Northern novelists, playwrights and poets generate characteristic vocabulary and grammar, ${ }^{6}$ forming a distinct representation of a specific geographic location, of a particular historical or political environment and of a recognisable literary imagery which stand in polemical contrast both to the diction of the South of the island and to the British literary traditions. ${ }^{7}$ Such authors as Stewart Parker, Anne Devlin, Martin Lynch, Graham Reid, Gary Mitchell, Marie Jones, Glenn Patterson or Michael Longley and Ciaran Carson provide wider context for Christina Reid's work. Their writings contribute to the formation of a distinct yet varied archipelago whose special location places it simultaneously within and outside typically Irish, English, European and Western literary and cultural circulation.

4 As one critic mentioned, "In the midst of this male-dominated Belfast drama [here mainly Martin Lynch, Graham Reid and Ron Hutchinson are mentioned. Added M.L.] it is a relief to find a woman playwright whose main interest is the human and social background of the Troubles, and in whose plays women are allowed to speak, not only occasionally, but quite often most of the time" (D. Roll-Hansen, "Dramatic strategy...,", p. 389).

$5 \quad$ R. O'Dwyer, "The imagination of women's reality: Christina Reid and Marina Carr”, [in:] E. Jordan (ed.), Theatre Stuff: Critical Essays on Contemporary Irish Theatre, Dublin: Carysfort Press, 2000, p. 240 .

6 Although as some critics claim it is possible to distil a set of characteristic features of the writing from the North. For Anthony Roche these plays are "antihierarchical"; they "move in opposition to the well-made-play, emphasising instead discontinuity, fragmentation and juxtaposition" (A. Roche, Contemporary Irish Drama, $2^{\text {nd }}$ ed., London: Palgrave, 2009, p. 159). In Roche's opinion this may look like a "new genre" (p. 159).

7 References to the South of Ireland are multiple in Northern Irish literature. In Joyriders there is a direct mention of Seán O'Casey, his play Shadow of the Gunman, and by implication to a specific concept of socialism which in the North naturally assumes a different form. Activities, in the field of culture but also social reform, of some Northern artists are also critically compared with those of the South especially at the time of the Celtic Revival. Alice Milligan, a playwright actively involved with the Ulster revival in Belfast has been compared to Maud Gonne, the paragon of artistic and political engagement from the Dublin period of Celtic Twilight (M. Phelan, "Beyond the pale: Neglected Northern Irish women playwrights, Alice Milligan, Helen Waddell and Patricia O'Connor", [in:] M. Sihra (ed.), Women in Irish Drama: A Century of Authorship and Representation, London: Palgrave, 2007, p. 120). 
It is, therefore, possible to see the literary production of the North of Ireland within a new set of categories, namely ones which are normally used to debate the subaltern literatures of African countries. Northern Irish literature may perhaps be productively framed between the opposition of the South and North; that is within the usual lines of discussion for economic, social and cultural conditions of life in southern countries in relation to Europe and the rest of the Western world. In case of Northern Ireland this division would be reversed, with the North representing an impoverished, underdeveloped zone of postcolonial and post-imperial politics, a victim of hegemonic domination of the British rule. Through its history the North requires a specific array of concepts for a meaningful analysis of its predicament. Moreover, an important question to debate is to what extent Northern Ireland squarely belongs to European culture, not just British, and to what extent it remains in a creative conflict with it due to its religious, cultural and economic development. Northern Ireland and its literary or dramatic output both belong and do not belong to the core of European politics but definitely acutely register its tensions and upheavals. ${ }^{8}$ All through the twentieth century, Irish and Northern Irish literature adapted and significantly reformulated literary styles as well as philosophical trends spawned in the schools of modernist or postmodernist thought. This article proposes to see Northern Irish literature as a field in which British and European intellectual trends and literary styles meet and collate with local linguistic and cultural idiom. Northern Irish culture would therefore be both a reflection of European art and politics and a prism through which they undergo a process of refraction and reformulation.

If by subaltern condition one defines a position in which social groups and countries are denied "access to «hegemonic» powers," and in which "they are always subject to the activity of ruling groups" through which they are "dominated by elitism", 9 and subsequently denied the right to govern their own affairs, the condition of Northern Irish communities can be seen as a product of such subaltern hegemony. The aim of this comparison is not to idly dilute philosophical concepts but to position a particular Northern Irish experience in concrete, well-defined political and cultural relations in order to analyse how it has been shaped and represented in a dramatic form. If, therefore, for Boaventura de Sousa Santos, Portuguese philosopher and sociologist, the South generates its own, very idiosyncratic "epistemology", and if such

8 The condition of being part of European tradition and simultaneously remaining on the outside of it, maintaining a critical distance has been phrased differently by different critics. For Anthony Roche "Language in the North is also a double-edged weapon. It offers a playwright a rich and varied dramatic speech, one saturated in the cadences and imagery of the King James's Bible [...], one drawing on a distinctive Anglo-Irish idiom and the subterranean influence of the Irish language [...]" (A. Roche, Contemporary Irish Drama, p. 158).

9 B. Ashcroft, G. Griffiths, H. Tiffin, Post-Colonial Studies: The Key Concepts, $2^{\text {nd }}$ ed., London: Routledge, 2000, pp. 198-199. 
"epistemologies of the south" are capable of critically redefining core European and Western values, then perhaps the specifically Northern Irish epistemology can do a similar thing to Britain and subsequently Europe. In other words, following de Sousa Santos in his analysis of Southern countries, Northern Ireland should also produce its own "epistemology", a recognisable body of experience as well as a variety of forms helping in giving it an adequate literary, historical and political representation. Furthermore, such an "epistemology" references back on European culture and politics, offering a distanced reading of its current condition.

For Santos, the South has been dominated by the "Eurocentric political imagination" which defines its own grammar and produces useful nouns. ${ }^{10}$ Eurocentric imagination refers to a selection of concepts and images which constitute a certain normative stereotype of European identity and character, a set of features which belong to a core definition of European state or citizen. Through its legislation and media EU institutions define the concept of European values, at the same time drawing a line beyond which lies the area of abnormality, and non-European standards. Naturally the normative European imagination, as Santos sees it, also generates its own language of description, what Santos calls "useful nouns," which brand otherness and mark out abnormality. The linguistic productivity which is at a full disposal of European institutions aims to produce an imagery of normative behaviour and to generate its theoretical justification. Therefore, what Santos terms "Eurocentric critical theory" has monopolized cultural analysis and imposed its leading tenets on other, differing communities and locations. ${ }^{11}$ Now, Santos claims, it is time for the South to challenge this "European universalism"12 and to compose a new "grammar of resistance" in which an "emancipatory political imagination" could be successfully brought to life. ${ }^{13}$ Santos proposes that the countries so far dominated with the European "universalism" have attempted to produce their own, dissenting, subversive narrative. In other words, Santos posits that much of what can now be said about the Western world originates in countries and communities geographically and mentally located outside of Europe and that such a "non-Western ethical, cultural, and political imagination" could perhaps help verbalize major European dilemmas and challenges. ${ }^{14}$ In his study, Santos speaks specifically of Africa, Asia and the Islamic world as grounds which could potentially breed new knowledge and provide alternative epistemology to the core of European values. Naturally, unlike the countries that Santos chooses for his analysis Northern Ireland remains part of Europe in a political and symbolic sense. However, the similar condition of subordination to British domination, as an example of general European doctrine of colonialism, makes Northern

10 B. de Sousa Santos, Epistemologies of the South: Justice against Epistemicide, London: Routledge, 2016, p. 59.

11 Ibidem, p. 8.

12 Ibidem, p. 15.

13 Ibidem, p. 18.

14 Ibidem. 
Ireland a likely location for developing a similarly sceptical imagination of dissent critically reviewing European politics and democracy of which European Union remains just a stage in a longer history of continental political systems.

The sense of being outside of the circulation which naturally drives metropolitan centers of literary and artistic creativity was strongly felt and clearly registered by writers or academics in the North. In 1970s, Seamus Heaney, whose early career of literary apprenticeship was spent among the teaching staff of Queen's University Belfast, recollected his early sense of marginalisation, which had not yet reached the stage of productive dissent: "It is easy to be blasé about all of that now, for now, of course, we're genuine parochials. Then we were craven provincials". ${ }^{15}$ The value of the creative marginalisation or privileged provincialism had not yet been decrypted in a group of writers who possessed energy but not faith in their own position. The Group, led by Philip Hobsbaum, collected writers and poets living in Belfast of the late 1960s and early 1970s, and eager to present their works in front of other emerging names on the Irish literary scene. Heaney observes that Hobsbaum, the nominal mentor and leader of the group, "emanated energy, generosity, belief in community, trust in the parochial, the inept, the unprinted". ${ }^{16}$ The "inept" and the "unprinted" suggest a culture in a state of infancy, a culture without representation, a culture without its own record, a culture unrecognised outside of its own, narrow milieu. In other words a culture waiting for its own story as opposed to defined cultural and political identities of Britain and Europe.

A similar, slightly ironically phrased sentiment is present in the writings of Stewart Parker, perhaps the most gifted and talented playwright from the North. In his scattered, short writings he voices an opinion on the sense of geographic and intellectual marginalisation which naturally bears on the condition of practical and artistic life in Belfast:

Personally, I love Belfast and hate it with an equal passion. In other words, it's my hometown. Growing up there in the '40s and '50s was like growing up in outer Greenland. I remember a school debate on the motion that the Irish Sea was wider than the Atlantic Ocean. Carried unanimously. ${ }^{17}$

A space which remains open to redefinition and in which possible redefinitions, carried through by popular vote, lose contact with reality escapes set doctrines, political schemes, universal agendas. Located on the margins, like "outer Greenland", the space invites ideas conducive to producing its own, local narrative irrespective of common logic or politics, oblivious of any form of official readings of history and ideology. If "European universalism" that de Sousa Santos sees as some pan-Euro-

15 S. Heaney, "Belfast", [in:] S. Heaney, Finders Keepers Selected Prose 1971-2001, London: Faber \& Faber, 2003, p. 39.

16 Ibidem.

17 S. Parker, "Belfast women: A superior brand of dynamite", [in:] G. Dawe, M. Johnston, C. Wallace (eds.), Stewart Parker: Dramatis Personae and Other Writings, Prague: Litteraria Pragensia, 2008, p. 86 . 
pean model for interpreting reality, really provides modern European citizens with a framework for thinking, then such places as Northern Ireland show considerable potential to subvert it.

In a poem "Belfast confetti," Ciaran Carson describes his war-invested home town, showing how place determines language, its syntax and vocabulary, how grammatical constructions depend on the feeling of material surface of streets and buildings. In this poem, the city-scape directly shapes the language of description, producing grammar generated by vicissitudes of life in a reality brimming with violence:

Suddenly as the riot squad moved in it was raining exclamation marks,

Nuts, bolts, nails, car-keys. A fount of broken type. And the explosion

Itself - an asterisk on the map. This hyphenated line, a burst of rapid fire ...

I was trying to complete a sentence in my head, but it kept stuttering,

All the alleyways and side-streets blocked with stops and colons. ${ }^{18}$

Carson also visualises Belfast as a model set to be assembled, confessing that:

Sometimes the city is an exploded diagram of itself, along the lines of a vastly complicated interactive model aircraft kit whose components are connected by sprued plastic latitudes and longitudes. [...] Now that I can see the city's microscopic bits transfixed by my attention, I wonder how I might assemble them, for there is no instruction leaflet; I must write it. ${ }^{19}$

What these examples naturally show is an alternative perception of space, an idiosyncratic nature of living in it and interpreting it. The production of language, narrative, story or a simple description involves applying special strategies, tactics of survival and endurance which testify to complex adjustments that the speaking subject needs to devise in order to successfully negotiate life within the political and social coordinates of a given geography. Thus, living in a place divided and controlled, confronting authority obsessed about imposing concrete restrictions on people's daily routines inevitably leads to discovering practical intelligence or a certain kind of awareness of how to preserve a degree of freedom, how to practice independence.

3.

All of Christina Reid's plays are deeply scarred with the sense of divided space. Locations of her drama, almost exclusively set in urban landscapes of side streets, back yards, gardens and domestic interiors of city dwellers, evoke spaces which represent long histories of conflict that has spread cracks across the map of human activities and routines. Physical walls, euphemistically called "peace walls", or mental di-

18 C. Carson, "Belfast confetti", https://www.poetryinternationalweb.net/pi/site/poem/item/27672 [access: 7.12.2018].

19 C. Carson, The Star Factory, London: Granta Book, 1998, p. 15. 
vision lines cut through ordinary paths, streets and districts of the city, imposing war logic on ordinary practices of life. Such symbolic, historical as well as concrete separation barriers determine how particular characters walk, do shopping, visit friends, commute to work, but also how they feel while engaging with the space around, what margin of freedom they are capable of hacking out of the solid block of political stale mate. This phenomenology of location produces idiosyncratic knowledge, it forces Reid's characters to reflect on their practices of every-day life, and thus it develops in her protagonists unique self-consciousness.

References to spaces are manifold, and they range from complaints about simple difficulties in moving across the city to reflecting on deep social, political and sectarian divisions. In The Belle of the Belfast City a character explains her being late by saying that "there was a demonstration earlier today near Belfast city center and some of the roads were still blocked". ${ }^{20}$ The family shop which provides a primary venue for action in the same play is located in the street "that the Army has closed to traffic". ${ }^{21}$ Disrupted movement in space not only reflects political rupture of the society deeply scarred by the province's historical conflicts, but also evokes a sense of entrapment in a more existential sense in which characters' views, beliefs and judgements belong to two warring ideological camps. In Joyriders, a play about a charity youth training center, the sense of living in a city divided by politics and politicians is permanent. Protestants fear showing up in the area because the premises of the youth center lie "not a stone's throw away from IRA territory". ${ }^{22}$ Irish people are encouraged to emigrate and to start a new life in safer destinations, free from military violence: "You will love America. You will be coming to a peaceful place, a happy place, a safe place. No rioting, no shooting, no bombs, no soldiers". ${ }^{23} \mathrm{Im}$ plicitly, Northern Ireland is assumed to offer no hope in ever freeing itself from the dangers of the military conflict. While a posh protestant street in Belfast, in which one of the female protagonists of the play lives, is appreciated for quiet, undisturbed atmosphere, the impoverished, troubled districts are populated by people mutilated by street bombs and left permanently disabled as an effect of sectarian violence. The notorious Divis Flats, an area of poor high-rise buildings in western Belfast, almost proverbially belongs to the most underinvested and neglected parts of the city plagued with rats and poisoned with asbestos (Divis Flats "where the happiest tenants are surely the rats"). ${ }^{24}$

Even the organisation of the municipal burials reflects unwritten laws of sectarian identity. In Tea in a China Cup Beth, trying to buy a grave plot for her mother, is instructed that the entire cemetery faithfully follows the religious rift that operates in the society: there is a separate area for Protestant and for Catholic plots, and - as

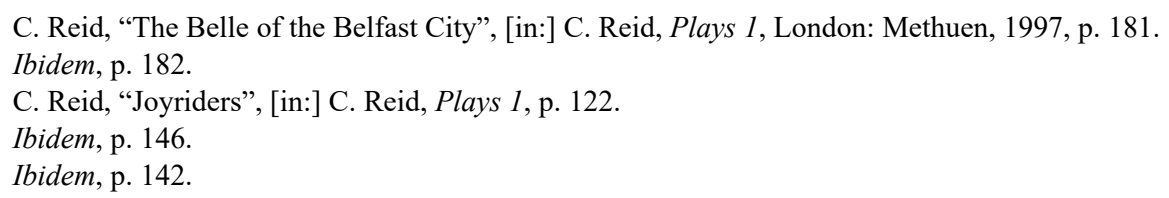


the character comments, "an odd one buried among the wrong crowd stands out like a sore thumb". ${ }^{25}$

Such examples taken from Reid's writing could be multiplied. Yet, while her main focus remains with the Protestant communities, she makes it clear that the same sense of fear, disruption, inequality and injustice haunts also the Catholic minority. All of her characters suffer economic and social injustice, living under constant threat of physical violence, which contradicts a stereotypical understanding of social relations in Ulster-that is the Loyalists seen as privileged both in the political and financial aspects of life. In Reid's writing, the lines of exclusion follow a completely different pattern and show a community of people who are united by the sense of being disenfranchised by elites regardless of their religious or political affiliation. Therefore by using recognisable topography of the conflict, she simultaneously dramatizes an unexpected record of human responses to it. Reid's characters slowly realise that they live on the margins of a democratic world in which public institutions, law and social justice have been compromised by semi-criminal regime of influence and power working in the interest of few non-democratic, paramilitary groups to the disadvantage of the majority. It is a picture of modern state which has desisted from its basic democratic responsibilities in a process of disintegration into violent anarchy. This landscape of devastation and ruin is populated by people victimised and threatened into submission; finally, it is a dystopian projection of the limits of a democratic political system.

Such a situation produced a culture of evasion, of submersion, of disappearance. Reid's characters possess a unique understanding of the system; as witnesses of its ruthless mechanism they turn into secret agents of rebellion and opposition. Retreating into the private sphere of family life, recollection, dance, or irony and humour, they manage to disappear from the public domain controlled by an active presence of nationalism, colonialism, class and economic divisions. They can acutely feel when their own language begins to function as a vehicle for political ideology, when it escapes their control, and when it is reduced to stand for some else's views and ideas. Constructing their own universe, Reid's female characters turn into self-conscious users of language, into speakers who realise that if true and sincere language is to function at all, if it is to maintain its syntagmatic and paradigmatic coherence, they need to repossess it in their own way and on their own terms. Therefore, often the impossibilities of life are cushioned with a controlled sense of humour verging on absurdity. Some of Reid's protagonists attempt to alienate their own fear, their sense of oppression, and disempowerment. In Joyriders, Brian — who is a jobless Catholic dating a "well-to-do Prod from up the Malone Road" - comments on how he is going to get his brother out of prison: "I tell you what. As soon as I get my Rambo outfit back from the cleaners, I'll scale the wire and carry our Joe out on my back". ${ }^{26}$ The

\footnotetext{
C. Reid, "Tea in a China Cup", [in:] C. Reid, Plays 1, p. 6.

C. Reid, "Did You Hear the One about the Irishman...?", [in:] C. Reid, Plays 1, p. 76.
} 
use of childish talk produces no real change but powerfully affects the perception of reality, turning it into softer, less scary image of life in the city dominated by violence. It exposes reality as unreal, as a world which has travelled beyond reason, which can be challenged only by scenarios unthinkable to those who have been dominated by official propaganda. Later on Brian observes that there is only one thing that unites the Irish-Long Kesh ${ }^{27}$ : "where else do you know of in Northern Ireland where the Prods and the Fenians meet on common ground?". ${ }^{28}$ This language points to the unthinkable, and it turns into counter-language, a language of contradiction, of paradox, of absurdity.

Reid dramatizes social conditions of life in which her protagonists suffer poverty and exclusion, consistently using a technique of absurd alienation and contradiction carefully integrated with the realistic representation of daily hardships. Therefore, hers is not a typically realistic drama. ${ }^{29}$ Reid deforms and dismantles social-realism of action, by inserting into it elements of the absurd, utopian or folk imagery; by doing that, she expands the scope of her argument and its challenging relevance to comment on the situation in Northern Ireland. In a Brechtian gesture of epic distancing, the young protagonists of Joyriders intersperse the realistic action of the play with songs:

We are the children of Divis Flats

And it's for houses that we're fighting

$[\ldots]$

They took our houses they gave us flats

How much longer must we live here?

$[\ldots]$

Among the rats, among the clocks

And breathing in asbestos. ${ }^{30}$

The disruption of action which needs to stop to make space for song and performance deprives it of its absolute character. This alternative flow of words, in a performed song, or in a recollected story, challenges the universal domination of the official story, offers an alternative perspective, changes the mood. Since the reality depicted in Reid's plays gives no hope of practical improvement, her protagonists are forced to apply a variety of such evasive strategies in order to work out some vocabulary of meaningful talk or communication. Reid also uses a Brechtian alienation effect in Did You Hear the One about the Irishman...? The figure of a Comedian, which

27 Long Kesh, also known as the Maze Prison, was a detention institution in Northern Ireland created to incarcerate members of paramilitary organizations, both republican and unionist.

28 C. Reid, "Did You Hear the One about the Irishman...?", p. 76.

29 As Roll-Hansen observes, "Christina Reid's strategy is very different indeed from that of conventional social realism. In fact, anti-naturalism would be an adequate description of her flexible post-Brechtian handling of the «changes of time and place», both delicate and spirited" (D. Roll-Hansen, "Dramatic strategy...”, p. 393).

30 C. Reid, "Joyriders", pp. 110-111. 
remains outside of the action as an external commentator, provides an ironic political and historical background to the dramatized events, but also offers jokes standing in contrast to the protagonists' tragic love story. Using the figure of "Little Paddy" as an object of ridicule, he applies mockery in the simple, plebeian style:

Did you hear the one about the Irishman whose plane ran out of peat? He radioed for help. Mayday! Mayday! 'Cleared to land,' answered Control. 'Can you give us your height and position?' 'Certainly,' said the Irishman, 'I'm five foot two and I'm sitting at the front of the plane.'”31

Reid's strategy is that of rejecting the dominating discourse of the Troubles and more specifically of looking for alternatives to the standard bifurcation of reality in which the Loyalist and the Republican perspectives always hold dominant positions. Her characters produce knowledge and perform actions which in the first place annul such divisions, and secondly rethink their own position in reference to already defined narratives. The protagonists live, then, in-between worlds, both in a zone of aggressive political reality and in a world of mock utopias, performed songs, private recollections, and comic shows staged in a domestic environment. This alternative reality offers a sheltered space of freedom in which human relations are based on mutual acceptance and sympathy. In the world apart of familial life, in which spontaneous human emotions are not controlled by political creed and religious dogma, Reid's protagonists expand beyond a single time zone or even one personality. In performed stories from the past they travel to distant locations, live through historical events and revisit emotions which belong to previous generations. Their personalities are inflated beyond standard naturalistic psychology, creating collective, magnified dramatic personae. Thus, in Tea in a China Cup Beth, one of the two female protagonists of the play stresses the fact that her cultural memory extends beyond her own life into the past which she did not have a chance to witness: "I can remember and see clearly things that happened even before I was born". ${ }^{32}$ The power of such images comes largely from the fact that most of Reid's plays are multi-generational sagas which reveal the history of a family across epochs. "Past" events are usually narrated in recollected visions or in meta-narrative stories produced by protagonists. As a result, the known reality or the big History undergoes a serious decomposition, since such private narratives always offer stories challenging official versions of the past. More importantly, meta-narrative recollections suggest private, sensitive interpretations of events, connecting facts with subjective emotions and motivation. Reid dramatizes a battle between an individual and a system, in which it is the system that ultimately betrays the individual, forcing him or her to fight against the manipulated logic of imposed values based on violent political ideology or fanatic conviction. The confrontation between the political reality and the private world of characters exposes the shortcomings of the state and its institutions responsible for social jus-

\footnotetext{
31 C. Reid, "Did You Hear the One about the Irishman...?", p. 69.

32 C. Reid, "Tea in a China Cup", p. 10.
} 
tice and political stability. Reid's plays show among other the weakness of the state, the corrupted operation of its legal system, the collapse of efficiency in dealing with social challenges.

Reid's uniquely sensitive characters rob the system of its appearances and expose not only what happens to a state devastated by years of violence and guerrilla fighting but also how existing law depletes and melts away to make space for injustice and power-struggle. In Reid's plays, various forms of physical and intellectual disability are used to expose rigid definitions of political and religious identity, of norm and freedom, of convention and taboo. Disabled characters are either immediate victims of military violence with bodies mutilated by bullets and explosions or mentally challenged individuals who register the sectarian tensions by losing their psychological stability. In all of these cases disabled characters are a mark of political injustice and sectarian violence, scarred by the conflict, bearing witness to ubiquitous hostility. They challenge the political reality not only as living symbols of injustice and terror but primarily by exposing the heartless indifference and dehumanised conduct of highly conservative and patriarchal society. There is no space to be occupied by disabled characters, there is no official or private recognition of their physical and mental weakness, they are ruthlessly pushed to the margins of their communities, left behind by institutions and individual leaders devoted to fighting for power and domination.

In Joyriders, one of the young men working in the youth club, who has been shot by the army, experiences constant nightmares and endlessly waits for the compensation. Another character's mother, who was injured by a plastic bullet, is forced to stay at home, doing nothing - "she just stares", ${ }^{33}$ as her daughter observes. In The Belle of the Belfast City Davy, a deaf and mute boy, displays a deep, uncritical fascination with a powerful Protestant politician regardless of his shady dealings with neo-fascist groups and in spite of the politician's plans leading to the destruction of his own family, the only circle of friendly people interested in helping the disabled boy. Reid uses vulnerability and weakness as a test to the justice and moral standards of the society. She illustrates what happens with a nation destroyed by paramilitary violence and criticises the domination of the Troubles theme over other aspects of social life. She is worried "about the trend to portray Ireland through its violence so all you see are the Troubles and you lose sight of the people". ${ }^{34}$ The practical disappearance of the society as a coherent structure of engaged individuals can be seen here as a result both of the colonial legacy of weakened democratic institutions and of internal violence.

As suggested earlier, Northern Irish drama represents in a more universal perspective a region on the margins of European or Western cultural circulation. A question worth asking is what does it teach its readers in terms of politics and culture. For one, plays by such playwrights as Christina Reid show that official institutionalized

\footnotetext{
33 C. Reid, "Joyriders", p. 119.

34 Quoted in: D. Roll-Hansen, "Dramatic strategy...", p. 390.
} 
narratives rarely reflect the grass-roots reality of life in a particular region. More importantly, she proves to what extent the basic democratic system gets hijacked by individual groups or political factions to realise their interests supposedly in the name of law. A new regime of injustice is introduced under the label of emancipation and equality which the more powerful sell to those in need. This is how de Sousa Santos defines "social fascism", as a strategy of imposing social solutions on weaker states which are unable to reject social help and thus must also accept economic and political domination that comes as part of the package. ${ }^{35}$ Those who reject the helping hand of such "hegemonic globalisation" remain in a social limbo with practically no rights. Against that Santos proposes a "baroque ethos", the new model of subjectivity in which utopian imagination allows for flexible sociability, for striking new, emancipatory relations. Baroque subjectivity is intent on practising the "imagination's exploration of new modes of human possibility and styles of will". ${ }^{36}$ Reid's characters who engage in their imaginative recollections, performances and mocking displays of disrespect towards the political reality in Northern Ireland could be seen as such "baroque" personalities. In Reid's case, it would refer to the dramatic protagonists who display a considerable social flexibility, irony and will in activities which undoubtedly carry some "emancipatory" potential.

The fact that Reid's penetrating inquiries concern mainly the Protestant community adds importance and resonance to her moral assessment of the political condition of Northern Ireland as well as England. In many ways, the images of Northern Irish Protestants affected by poverty and violence and left to their own devices by the British government together with the local authorities reflect back on the unstable condition of the United Kingdom and the decomposition of its basic values. Writing about the "post-UKanian" condition in Anglo-Irish relations, Edna Longley observed that there came the time to ask the "national question again". ${ }^{37}$ As the "multi-national state crumbles and changes", the definition and understanding of "Englishness" also undergoes a decisive evolution. She sees Ulster Protestants as "bereft of superstructure" and as an alienated outpost whose mainland lost its solid ground and now melts away as the traditional Englishness "may have been hollowed out by ukanian and imperial ventures which have changed the «home» population" ${ }^{38}$ Ulster Protestants would then be in Longley's view "forced back on the regional modes of their self-articulation". ${ }^{39}$ My proposition would be to say that the implications of Christina Reid's pessimistic views of Ulster Protestants reflect back more generally on the entire European/Western — not only ukanian condition. It is not only Englishness

${ }_{35}$ Cf. Santos, chapter One. B. de Sousa Santos, Epistemologies of the South...

36 B. de Sousa Santos, Epistemologies of the South ..., p. 94.

37 E. Longley, "Northern Irish writing: Post-Ukanian perspectives", [in:] M.H. Mutran, L.P.Z. Izarra (eds.), Kaleidoscopic Views of Ireland, São Paulo: Humanitas (Universidade de São Paulo), 2003, p. 31 .

38 Ibidem, p. 31.

39 Ibidem. 
that has undergone an evolution towards a loser, more vague definition of its basic principles of democracy and social welfare, but the entire European project crumbles in the face of the rising appeal of populistic rule supported with blatant nationalistic sentiment. Such extreme sentiments take control of local communities, forcing people - like Reid's characters - to withdraw into the privacy of family life, into the world of domestic activities. Reid described the mechanism of disappearance from the public sphere which produced in her protagonists a feeling of both frustration and emancipation. In this sense, the Northern Ireland of the 1980s seen through Christina Reid's eyes anticipates many social and political changes in contemporary Europe. The alienation of member states and individual communities from the idea of the union, the rise of local extremisms and nationalisms, the increasing lack of faith in common, European institutions coupled with individual attempts at emancipation through anarchic and ironic dissent.

\section{References}

Ashcroft, B., Griffiths, G., Tiffin, H., Post-Colonial Studies: The Key Concepts, $2^{\text {nd }}$ ed., London: Routledge, 2000.

Carson, C., The Star Factory, London: Granta Book, 1998.

Carson, C., "Belfast confetti", https://www.poetryinternationalweb.net/pi/site/poem/item/ 27672 [access: 7.12.2018].

Delgado, M.M., "Introduction”, [in:] Ch. Reid, Plays 1, London: Methuen, 1997, pp. vii-xxii. Heaney, S., "Belfast", [in:] S. Heaney, Finders Keepers: Selected Prose 1971-2001, London: Faber \& Faber, 2003, pp. 39-45.

Longley, E., "Northern Irish writing: Post-Ukanian perspectives", [in:] M.H. Mutran, L.P.Z. Izarra (eds.), Kaleidoscopic Views of Ireland, São Paulo: Humanitas (Universidade de Saõ Paulo), 2003, pp. 27-53.

O'Dwyer, R., "The imagination of women's reality: Christina Reid and Marina Carr", [in:] E. Jordan (ed.), Theatre Stuff: Critical Essays on Contemporary Irish Theatre, Dublin: Carysfort Press, 2000, pp. 236-249.

Parker, S., "Belfast women: A superior brand of dynamite", [in:] G. Dawe, M. Johnston, C. Wallace (eds.), Stewart Parker: Dramatis Personae and Other Writings, Prague: Litteraria Pragensia, 2008, pp. 86-90.

Phelan, M., "Beyond the pale: Neglected Northern Irish women playwrights, Alice Milligan, Helen Waddell and Patricia O'Connor", [in:] M. Sihra (ed.), Women in Irish Drama: A Century of Authorship and Representation, London: Palgrave, 2007, pp. 109-130.

Reid, C., "Did You Hear the One about the Irishman...?", [in:] C. Reid, Plays 1, London: Methuen, 1997, pp. 67-99.

Reid, C., "Joyriders", [in:] C. Reid, Plays 1, London: Methuen, 1997, pp. 99-177.

Reid, C., "Tea in a China Cup", [in:] C. Reid, Plays 1, London: Methuen, 1997, pp. 1-67.

Reid, C., "The Belle of the Belfast City", [in:] C. Reid, Plays 1, London: Methuen, 1997, pp. 177-251.

Roche, A., Contemporary Irish Drama, $2^{\text {nd }}$ ed., London: Palgrave, 2009. 
Roll-Hansen, D., "Dramatic strategy in Christina Reid's Tea in a China Cup", Modern Drama 1987, vol. 30(3), pp. 389-395.

Santos, de Sousa B., Epistemologies of the South: Justice against Epistemicide, London: Routledge, 2016.

Tracie, R., Christina Reid's Theatre of Memory and Identity: Within and Beyond the Troubles, Cham: Palgrave Macmillan, 2018. 